\title{
Técnicas de transformação e linhagens de Agrobacterium rhizogenes na produção de hairy roots de Ocimum basilicum L.
}

\author{
José NICOMEDES JÚNIOR ${ }^{1}$, Roberta Cristiane RIBEIRO ${ }^{2 *}$, Luis Louro BERBARA ${ }^{3}$, \\ Elvia Mariam Lis Martinez STARK ${ }^{3}$, Wagner Campos OTONI ${ }^{4}$, Sónia Regina SOUZA ${ }^{5}$
}

\footnotetext{
${ }^{1}$ Centro de Pesq. e Desen. Leopoldo Américo Miguêz de Mello, Universidade Federal do Rio de Janeiro, Rio de Janeiro, RJ, Brasil. ${ }^{2}$ Instituto de Educação, Ciência e Tecnologia de Mato Grosso, Sorriso, MT, Brasil.

${ }^{3}$ Departamento de Solos, Universidade Federal Rural do Rio de Janeiro, Seropédica, RJ, Brasil.

${ }^{4}$ Departamento de Biologia Vegetal, Universidade Federal de Viçosa, Viçosa, MG, Brasil.

${ }^{5}$ Departamento de Química, Universidade Federal Rural do Rio de Janeiro, Seropédica, RJ, Brasil.

*E-mail: robertacristiane@gmail.com
}

Recebido em julho/2017; Aceito em dezembro/2017.

\begin{abstract}
RESUMO: O manjericão é uma planta medicinal e seus metabólitos especiais são utilizados com fins terapêuticos e industriais. Este trabalho teve por objetivo avaliar técnicas e linhagens de Agrobacterium rhizogenes na produção de raízes transformadas de duas variedades de Ocimum basilicum L., Dark Opal (roxo) e Minete Anão (verde). Verificou-se o efeito da inoculação com linhagens de $A$. rhizogenes selvagens (A4, 8196, 9402, 2659, 2659 G, 17242, LBA, 15834) ou transformadas (R1601) em plantas inteiras ou explantes (folhas e segmentos de caule) de manjericão, cultivados em casa de vegetação ou in vitro. A inoculação com as linhagens LBA e 8196 possibilitou redução no número de explantes de folha de manjericão-verde oxidados, quando comparado ao controle. Dentre as linhagens selvagens, as que proporcionaram melhor indução na produção de raízes transformadas foram A4, LBA e 8196, respectivamente. Entretanto, a cepa R1601 apresentou a melhor resposta. Raízes foram eficientemente induzidas mediante a inoculação de explantes de manjericão-roxo e manjericão-verde e expressaram o fenótipo típico de raízes em cabeleira (hairy roots). As culturas clonais de manjericão-verde apresentaram rápido crescimento em meio de cultura livre de reguladores de crescimento.
\end{abstract}

Palavras-chave: agrobactéria, cultura de raízes, manjericão, plantas medicinais.

\section{Transformation techniques and Agrobacterium rhizogenes strains in the production of hairy roots of Ocimum basilicum L.}

\begin{abstract}
Basil is a medicinal plant and its special metabolites are used for therapeutic or industrial purposes. The aim of this work was to evaluate Agrobacterium rhizogenes techniques and strains in the production of hairy roots of two varieties of Ocimum basilicum L., Dark Opal (purple) and Dwarf Racer (green). The effects of inoculation of $A$. rhizogene (A4, 8196, 9402, 2659, 2659, 2659 G, 17242, LBA, 15834) or (R1601) lines on whole plants or explants (leaves and stem segments) of basil, grown in a greenhouse or in vitro, in the production of hairy roots and calluses made by subcultures. Inoculation with the LBA and 8196 lines allowed a reduction in the number of oxidized basil-green leaf explants when compared to the control. Among the wild strains, those that had best ability to induce hairy root of hairy roots were A4, LBA and 8196, respectively. However, the R1601 laboratory strain had the best response. Roots were efficiently induced by the inoculation of explants basil-purple and basil-green and expressed the typical phenotype of hairy roots. Greenbasal clonal cultures showed rapid growth in culture medium free of growth regulators.
\end{abstract}

Keywords: agrobacterim, basil, medicinal plants, root culture.

\section{INTRODUÇÃO}

Os vegetais, via produtos naturais, tem proporcionado a construção de propostas de modelos químicos, assim como, a descoberta de novas substâncias com atividade biológica (KINGHORN et al., 2011; CRAGG; NEWMAN, 2012). Cerca de $65 \%$ dos fármacos aprovados nas últimas três décadas são derivados e estruturados em arquitetura molecular proveniente de vegetais. A busca por essas substâncias de origem vegetal vem superando os avanços sobre drogas puramente sintéticas, mesmo estando associada a dificuldades devido à complexidade de sua obtenção. Em consonância a isso, é forte a tendência de desaparecimento das espécies vegetais bioprodutoras dos agentes químicos, principalmente devido os procedimentos inadequados de colheita e extração (ATANASOV et al., 2015).

Essas limitações podem ser superadas com o uso de culturas de raízes transformadas "hairy roots", produzidas por espécies infectadas pela bactéria Agrobacterium rhizogenes, que transfere parte de seu DNA plasmidial (TDNA) ao genoma nuclear da célula vegetal. Uma vez integrado ao genoma da planta, o T-DNA é transcrito e traduzido em proteínas e enzimas responsáveis pelo envio desse fragmento de DNA da bactéria ao vegetal. Além de induzir a síntese de hormônios e opinas, pela planta, que são utilizadas pelas agrobactérias como fonte de energia. Já os hormônios provocam um desbalanço no metabolismo das 
células vegetais, que passam a se propagar desordenadamente, induzindo a formação de raízes. A literatura descreve que essa associação se dá por quimiotactismo, uma vez que existem diferenças na virulência das linhagens dessas agrobactérias (BHATTACHARYYA et al., 2014). Dessa forma, para melhorar o entendimento das interações entre bactéria e planta hospedeira, é de extrema importância estudar as linhagens com potencial de infecção.

Essas culturas de raízes transgênicas normalmente apresentam taxas de crescimento superiores àquelas observadas em raízes não transformadas e, ao mesmo tempo, possibilita a produção de metabólitos especiais bioativos (FILOVÁ, 2014). O que pode levar à preservação das espécies vegetais, ao mesmo tempo em que se emprega a tecnologia da recombinação gênica, para produzir raízes transgênicas com potencial de produção de metabólitos secundários em um sistema fechado (GEORGIEV et al., 2012; NESTER, 2015; GAI et al., 2015). Além disso, nestas condições o risco de contaminação diminui, pois deixa de existir liberação ao meio ambiente de plantas geneticamente modificadas, uma vez que raízes transgênicas não apresentam estrutura de reprodução e apenas sobrevivem em ambiente controlado de laboratórios e indústrias (bioreatores, placas de Petri, etc.). Neste sentido a avaliação de linhagens de bactérias mais infectivas para cada espécie vegetal defini o sucesso da obtenção de hairy roots.

Dentro desse contexto, a espécie Ocimum basilicum L. também popularmente conhecida como manjericão é uma planta aromática que produz grande quantidade de substâncias químicas, o que the confere dentre outras características, propriedades benéficas a saúde. (GAI et al., 2015). Tendo em vista sua relevância química, o Ocimum basilicum L., tem sido amplamente utilizado, tanto na indústria farmacêutica como na alimentícia e cosmética (CHHETRI et al., 2015). Dentro do seu perfil químico se encontram diversos metabólitos secundários, como os compostos fenólicos, com destaque para o antioxidante ácido rosmarínico e o ácido litospérmico (SRIVASTAVA et al., 2016; TADA et al., 1996). O óleo essencial do manjericão, constituído majoritariamente pelo linalol e o metil chavicol (CHENNI et al., 2016) apresenta alto valor

Assim o objetivo do presente trabalho foi avaliar técnicas e linhagens de Agrobacterium rhizogenes na produção de raízes transformadas de Ocimum basilicum L.

\section{MATERIAL E MÉTODOS}

Os ensaios foram conduzidos em casa de vegetação e em laboratório, localizado no Departamento de Química do Instituto de Ciências Exatas, na Universidade Federal Rural do Rio de Janeiro, Campus de Seropédica - RJ.

$\mathrm{O}$ cultivo no ensaio em casa de vegetação, foi realizado em vasos com capacidade de $2 \mathrm{~L}$, contendo terra proveniente de um Argissolo Vermelho-Amarelo, sendo as plantas produzidas a partir da germinação de sementes mantidas (seis plantas/vaso) em cultivo por 45 dias até a inoculação. Tal procedimento e plantas foram utilizadas nos ensaios I e II.

Para os ensaios III e IV, que utilizou o cultivo in vitro foram utilizadas plantas de cultivos assépticos produzidas em condições controladas (laboratório) utilizando câmara de crescimento a partir de sementes germinadas em meio de cultura MS (MURASHIGE; SKOOG, 1962) a 1/2 força iônica e com repicagens em placas de Petri.

\subsection{Ensaio I}

Objetivou-se realizar uma triagem entre todas as linhagens de $A$. rhizogenes selvagens disponíveis e assim selecionar as linhagens mais infectivas, quando inoculadas em plantas inteiras, para as variedades de manjericão utilizadas.

As linhagens de $A$. rhizogenes selvagens utilizadas neste ensaio foram disponibilizadas junto a Empresa Brasileira de Pesquisa Agropecuária (EMBRAPA) Centro Nacional de Recursos Genéticos e Biotecnologia (CENARGEN) e a Universidade Estadual do Rio de Janeiro (UERJ), sendo oito linhagens conforme segue: A4, 8196, 9402, 2659, 2659 G, 17242, LBA, 15834.

Para a obtenção dos inóculos das linhagens de $A$. rhizogenes utilizados no ensaio I, conduzido em casa de vegetação, foi realizado o cultivo em meio YMB (Yeast Malte Broth) sólido por duas semanas. Uma colônia de cada uma das oito linhagens avaliadas foi inoculada em $10 \mathrm{ml} \mathrm{de}$ meio de crescimento líquido. As bactérias foram incubadas em agitador orbital (100 a $150 \mathrm{rpm}$ ), à temperatura de 25 a 28 ${ }^{\circ} \mathrm{C}$. Essas culturas de bactérias atingem a fase de crescimento exponencial $\left(\mathrm{A}_{600}=0,5\right.$ a 1,0$)$ entre 12 e 16 horas, sendo, portanto, esse o tempo no qual elas ficaram incubadas. Uma alíquota de 1,5 ml de cada suspensão bacteriana foi então transferida para um tubo de microcentrífuga estéril e centrifugada a 14.000 giros durante 3 minutos. $O$ sobrenadante foi descartado e as células foram ressuspendidas em $300 \mu \mathrm{l}$ em solução salina $\mathrm{NaCl}$ 0,85\%.

As seis plantas que foram mantidas em cada vaso foram lesionadas com palitos de madeira. O procedimento de infecção das plantas, foi efetuado com palitos que tiveram a ponta imersa na suspensão bacteriana preparada por cinco minutos, sendo em seguida as plantas feridas com a ponta do mesmo. Os locais de infecção foram envolvidos por filme plástico de PVC para evitar desidratação.

O crescimento e desenvolvimento dos calos e das raízes em cada ponto de infecção foi observado e seu desenvolvimento monitorado semanalmente, onde se observou a formação de raízes adventícias a partir dos explantes, tendo-se o controle como referência.

Os tumores e raízes obtidos foram extraídos das plantas, lavados em etanol $70 \%$, por um minuto, e desinfetados em uma solução de hipoclorito de sódio $1 \%$ por 20 minutos.

Os tecidos foram mantidos por oito horas em solução de tetraciclina (25 $\left.\mathrm{mg} \mathrm{L}^{-1}\right)$, sob agitação (50 a $\left.100 \mathrm{rpm}\right)$. O material foi então seco em papel filtro esterilizado.

Os tumores ou raízes foram então transferidos para placas de Petri contendo meio de cultura B5 $1 / 2$ força iônica sem regulador de crescimento, contendo $500 \mathrm{mg} \mathrm{L}^{-1}$ de cefotaxima sódica. As placas foram mantidas em câmaras de crescimento, no escuro, a $25{ }^{\circ} \mathrm{C}$. Ao final do ensaio foram selecionadas as linhagens que apresentaram melhor infecção.

\subsection{Ensaio II}

O objetivo foi avaliar as três melhores linhagens de $A$. rhizogenes conforme seleção realizada no ensaio I, quanto à capacidade de infectar explantes vegetais oriundos de plantas inteiras de duas variedades de $O$. basilicum L. (manjericão) cultivadas em casa de vegetação. 
Para a obtenção dos explantes vegetais do ensaio II a metodologia utilizada foi uma adaptação do método de CIAU-UITZ et al. (1994), onde foram retirados discos foliares de $0,8 \times 0,8 \mathrm{~cm}$. Estes foram lavados em etanol 70\%, por um minuto, e desinfetados em uma solução de hipoclorito de sódio $2 \%$ por 20 minutos, sendo lavados em água destilada estéril por três vezes.

As linhagens selvagens de $A$. rhizogenes utilizadas no ensaio em casa de vegetação foram as A4, LBA e 8196. Essas foram pré-selecionadas a partir do ensaio I realizado anteriormente, cujo o objetivo foi selecionar as linhagens que apresentaram melhor desempenho quando inoculadas em plantas inteiras.

A obtenção dos inócuos das linhagens de A. rhizogenes utilizados foram os mesmos descritos no ensaio I.

Em relação aos métodos de inoculação dos explantes vegetais oriundos de plantas cultivadas em vasos, foram utilizados cinco discos foliares por placa de Petri, contendo meio B5 $1 / 2$ força iônica adicionado de $500 \mathrm{mg} \mathrm{L}^{-1}$ de cefotaxima sódica. Os explantes de manjericão foram inoculados com cada estirpe de agrobactéria, sendo feitas cinco repetições para cada linhagem de bactéria. Como controle foram mantidas cinco placas onde os explantes receberam apenas solução salina $0,85 \%$. Após 15 dias, foi feita a avaliação do ensaio, no qual se identificou a formação de raízes adventícias a partir dos explantes, tendo-se o controle como referência.

\subsection{Ensaio III}

Foi avaliada a inoculação de explantes de duas variedades de manjericão cultivadas in vitro com três linhagens selvagens de $A$. rhizogenes previamente selecionadas no ensaio I. Neste ensaio utilizou-se explantes das plantas de manjericão oriundas do cultivo in vitro, infectadas com a estirpe produzida em laboratório, R1601 de A. rhizogenes. Essa linhagem contém o gene nptII sob o controle do promotor CaMV 35S, utilizada em experimentos de transformação gênica, sendo considerada supervirulenta (BORGO et al., 2015). Essa linhagem foi obtida junto a Universidade Federal de Viçosa - (UFV).

A morfogênese e o padrão de desenvolvimento das raízes através dos explantes foi avaliado para a estirpe R1601.

Nos ensaios de cultivo in vitro, as sementes de manjericão foram desinfestadas por imersão em álcool etílico a $70 \%(\mathrm{v} / \mathrm{v})$ por 60 segundos, pela imersão em solução de hipoclorito de sódio a 2,5\% (v/v) acrescidos de $1 \%(\mathrm{v} / \mathrm{v})$ de Tween 20, por 20 minutos, seguidas de 3 enxagues em água destilada e autoclavada. Em seguida, as sementes foram inoculadas em meio de cultura composto da metade da concentração dos sais básicos de MS (MURASHIGE; SKOOG, 1962), e suplementados pelo complexo vitamínico B5, $50 \mathrm{mg} \mathrm{l}^{-1}$ de meio-inositol, 2\% (p/v) de sacarose, 0,8\% $(\mathrm{p} / \mathrm{v})$ de ágar (Sigma Chemical Co., USA) sendo o $\mathrm{pH}$ ajustado em 5,7 $\pm 0,1$ antes da autoclavagem. O meio foi vertido em frascos de vidro de $350 \mathrm{ml}$ de capacidade, contendo aproximadamente, $50 \mathrm{ml}$ de meio em cada e vedados com tampas de polipropileno. Após o processo de autoclavagem e solidificação do meio, foram inoculadas 25 sementes por frasco. As culturas foram transferidas para sala de crescimento e mantidas sob irradiância em torno de 36 $\mu$ moles $\mathrm{m}^{-2} \mathrm{~s}^{-1}$, temperatura de $26 \pm 2{ }^{\circ} \mathrm{C}$, e fotoperíodo de 16 horas (lâmpada Gro-Lux Sylvania intercalada com lâmpadas fluorescentes, $20 \mathrm{~W}$, Osram, Brasil). Plântulas de 30 dias de idade, contados a partir da emissão de radícula, foram utilizadas como fonte de explantes. As plântulas foram retiradas do meio de cultura, e sob condições assépticas, utilizadas para os trabalhos de transformação. As mesmas foram separadas e suas folhas e caule foram individualizados. Das folhas retirou-se o pecíolo e os bordos, para aumentar a exposição das células vegetais à bactéria.

Em cultivo in vitro, a obtenção do inóculo das linhagens de $A$. rhizogenes foi a partir de cultivo em meio líquido YMB (20 $\mathrm{ml} \mathrm{em} \mathrm{frascos} \mathrm{Erlemeyer} \mathrm{de} 100 \mathrm{ml}$ ) por 24 horas, no escuro, sob rotação (100 rpm). Uma amostra de $200 \mu \mathrm{l}$ do meio de crescimento da bactéria foi adicionada à $20 \mathrm{ml}$ de meio líquido B5 a $1 \frac{1}{2}$ força iônica, em frascos de Erlemeyer de $100 \mathrm{ml}$.

No ensaio com explantes de plantas in vitro foram usados seis folhas e segmentos de caule por placa de Petri (cinco placas, totalizando 5 repetições), contendo meio B5 $1 / 2$ força iônica com $500 \mathrm{mg} \mathrm{L}^{-1}$ de cefotaxima sódica. A inoculação foi feita baseada em protocolo proposto em Tada et al. (1996), que demonstrou ser bastante eficiente para esta espécie vegetal. Os explantes de folha e segmentos nodais foram adicionados ao meio de cultura YMB contendo cultura da bactéria, em frascos Erlemeyer de $100 \mathrm{ml}$. Os explantes e a bactéria formaram uma co-cultura por dois dias, no escuro, sob rotação (100 rpm). Os explantes infectados foram então lavados com água destilada estéril, e transferidos para meio MS ou B5 a $1 \frac{1}{2}$ força iônica sólido, contendo o antibiótico Cefotaxima $\left(500 \mathrm{mg} \mathrm{L}^{-1}\right)$.

\subsection{Ensaio IV}

Utilizou-se explantes das plantas de manjericão oriundas do cultivo in vitro, infectadas com a estirpe produzida em laboratório, R1601 de A. rhizogenes. Essa linhagem contém o gene $n p t \mathrm{II}$ sob o controle do promotor CaMV $35 \mathrm{~S}$, utilizada em experimentos de transformação gênica, sendo considerada supervirulenta (BORGO et al., 2015).

Essa linhagem foi obtida junto a Universidade Federal de Viçosa - (UFV).

Assim como no ensaio III, a morfogênese e o padrão de desenvolvimento das raízes através dos explantes foi avaliado para a estirpe R1601.

Para obtenção do inóculo utilizado no ensaio em que foi avaliada a estirpe R1601, o procedimento adotado foi por culturas líquidas iniciadas mediante transferência de uma colônia isolada crescida em meio sólido, para $10 \mathrm{ml}$ de meio Rhizo líquido, contendo a concentração adequada de antibióticos de seleção (ampicilina a $100 \mathrm{mg} \mathrm{L}^{-1}$ e canamicina a $100 \mathrm{mg} \mathrm{L}^{-1}$ ). O período de incubação foi de 12 a 16 horas, à temperatura de $28{ }^{\circ} \mathrm{C}$, no escuro, sob agitação orbital de 100 rpm. O crescimento bacteriano foi monitorado por leituras espectrofotométricas a $600 \mathrm{~nm}$, e, uma vez atingido o valor de densidade ótica $(\lambda=60 \mathrm{~nm})$ de 0,6 , o crescimento foi interrompido, a suspensão centrifugada (4.000 rpm/ $10 \mathrm{~min})$, o sobrenadante descartado, e, substituído por igual volume de meio MS líquido.

Aos 30 dias de cultivo, plantas de manjericão foram separadas e então as folhas e caules e imersos por 20 minutos em meio de cultura Rhizo (acrescido de $100 \mathrm{mg} \mathrm{L}^{-1}$ do antibiótico ampicilina e $100 \mathrm{mg} \quad \mathrm{L}^{-1}$ do antibiótico 
canamicina) contendo a bactéria em crescimento. Os explantes inoculados (cinco) foram mantidos em co-cultura por 24 horas, sendo posteriormente transferidos para meio de cultura MS sólido $1 / 2$ força iônica acrescido de cefotaxima (500 mg L $\mathrm{L}^{-1}$ ). Foram, então, cultivados em sala de crescimento sob irradiância em torno de $36 \mu$ moles $\mathrm{m}^{-2} \mathrm{~s}^{-1}$, temperatura de $26 \pm 2{ }^{\circ} \mathrm{C}$, e fotoperíodo de 16 horas (lâmpada Gro-Lux Sylvania intercalada com lâmpadas fluorescentes, Luz do Dia Especial, 20 W, Osram, Brasil), até que ocorresse a diferenciação de raízes. Raízes começaram a aparecer após 15 dias de cultivo, sendo excisadas e transferidas aos 20 dias.

A contaminação endógena por estes microrganismos foi avaliada visualmente (Pereira et al., 2011). Os dados de morfogênese foram analisados por cálculo de porcentagem.

\subsection{Manutenção e caracterização das raízes}

Em relação a manutenção das raízes obtidas, em todos os ensaios foi utilizado o procedimento de cultivo em placas de Petri contendo meio B5 sólido $1 / 2$ força iônica, e quantidades de antibiótico Cefotaxima que foi, gradativamente, retirada do meio, até completa eliminação das agrobactérias. A concentração inicial do antibiótico no meio foi de $500 \mathrm{mg} \mathrm{L}^{-1}$, sendo reduzida à metade a cada repicagem. Foram feitas quatro repicagens com intervalos de 20 dias entre elas.

Para a confirmação das raízes transformadas foram realizadas reações da polimerase em cadeia (PCR), utilizando-se 'primers' específicos para o gene npt II. O DNA genômico de raízes de regenerantes foi extraído, segundo metodologia de Ferreira; Grattapaglia (1996), e utilizado para confirmação dos transformantes. As reações de amplificação foram realizadas com volume total de $25 \mu$, com $100 \mu \mathrm{M}$ de cada dATP, dCTP, dGTP e dTTP; $10 \mathrm{mM}$ de tampão (Tris $\mathrm{KCl}, \mathrm{pH} 8,3$ ); $2 \mathrm{mM}$ de $\mathrm{MgCl}_{2}, 20$ pmol de cada 'primer'; $50 \mathrm{mM}$ de $\mathrm{KCl}, 20 \mathrm{ng}$ de DNA; e $1 \mathrm{u} / \mu \mathrm{l}$ de Taq DNA polimerase. A seqüência dos 'primers' ("Life Technologies, Inc.", Rockville, EUA) são relacionadas abaixo NPT r (G C G G T C A G C C C A T T C G C C G C C) e NPT f (T C A G C G C A G G G G C G C C C G G T T). Como controle negativo foi utilizado DNA de tecidos vegetais não transformados e como controle positivo plasmídeos purificados, contendo o gene nptII (BHATTACHARYYA et al., 2014; NYABOGA et al., 2015).

Os fragmentos amplificados foram separados em gel de agarose $1,0 \%$, mediante o uso de tampão TAE 0,5 X, e após coloração com brometo de etídio, a imagem foi capturada no sistema Eagle Eye (Stratagene).

\section{RESULTADOS}

O cultivo de plantas inteiras de manjericão em casa de vegetação, ensaios I e II, mostrou diversos desafios a serem superados para a utilização de plantas não cultivadas in vitro na obtenção de hairy roots. Foi observado de forma expressiva a contaminação endógena das amostras oriundas do cultivo em casa de vegetação, por fungos e bactérias.

Esse ensaio representou a avaliação de um método que serviu para orientar de forma simples quais as estirpes apresentaram a melhor interação com as plantas de manjericão das duas variedades estudadas.

Para isso acompanhou-se o desenvolvimento das raízes (antecedido ou não pela formação de tumor) a partir do sítio de infecção nas plantas cultivadas em solo e inoculadas com A. rhizogenes.

Neste ensaio as estirpes selvagens que tiveram êxito na infecção de manjericão foram: A4, LBA e 8196. Em todas as seis plantas inoculadas por estas estirpes, em cada um dos pontos de infecção se verificou a formação de galhas e raízes, ou seja, manifestaram todos os sintomas característicos do processo de infecção.

Houve grande contaminação endógena do material colocado em meio de cultura estéril em placas de Petri (cerca de $70 \%$ das placas contaminadas). Os explantes que não contaminaram, inclusive controle, produziram raízes. Essas raízes foram então isoladas em meio B5 $1 / 2$ força iônica líquido, onde foi observado crescimento das mesmas após serem retiradas dos explantes.

Quando se utilizou material vegetal proveniente de plantas cultivadas in vitro os problemas com contaminação endógena, observados quando se utilizou explantes retirados de plantas cultivadas em casa de vegetação, foram visualmente contornados.

Com relação a concentração do inóculo bacteriano, foi possível observar que o seu ajuste é muito importante, principalmente para a linhagem A4, que foi bastante agressiva, competindo com os explantes durante o co-cultivo, o que foi demonstrado pela elevada taxa de oxidação e necrose observada nos explantes produzidos com essa linhagem.

A morfogênese e desenvolvimento dos explantes inoculados com as linhagens 8196 e LBA foram diferentes entre si, bem como o do controle. Os explantes inoculados com 8196 apresentaram maior formação de calos, sendo que estes antecederam a formação das raízes. Já nos explantes inoculados com a linhagem LBA a formação das raízes foi direta, sem a prévia formação de calos no sítio de infecção.

Os resultados mostram que ocorreu variação na morfogênese dos explantes de folha e segmentos de caule de manjericão, quando inoculados com diferentes linhagens selvagens de $A$. rhizogenes (Tabela 1 ).

Tabela 1. Respostas morfogênicas apresentadas por explantes de folha e segmentos de caule de manjericão-verde var. Minete Anão, 20 dias após inoculação com diferentes linhagens selvagens de Agrobacterium rhizogenes (30 explantes/linhagem de bactéria)

Table 1. Morphogenic responses presented by leaf explants and stem segments of basil-green var. Racer, 20 days after inoculation with different wild strains of Agrobacterium rhizogenes (30 explants / bacterial lineage).

\begin{tabular}{lcccccc}
\hline \multirow{2}{*}{$\begin{array}{l}\text { Linhagens de } \\
\text { Agrobacterium }\end{array}$} & \multicolumn{3}{c}{$\begin{array}{c}\text { Explante de } \\
\text { folha }\end{array}$} & $\begin{array}{c}\text { Explante de seg. de } \\
\text { caule }\end{array}$ \\
\cline { 2 - 7 } & $\mathrm{R}$ & $\mathrm{C}$ & $\mathrm{N}$ & $\mathrm{R}$ & $\mathrm{C}$ & $\mathrm{N}$ \\
\hline 8196 & 13,3 & 0 & 53,3 & 53,3 & 0 & 0 \\
\hline LBA & 46,7 & 3,3 & 0 & 10 & 0 & 73,3 \\
\hline A4 & 0 & 3,3 & 90,0 & 16,7 & 0 & 3,3 \\
\hline Controle & 20,0 & 0 & 86,7 & 73,3 & 3,3 & 0 \\
\hline
\end{tabular}

R: Raiz; C: Calo; N: necrose

As estirpes LBA e 8196 reduziram a oxidação e necrose dos explantes de folha de manjericão-verde ( 0 e 53,5\%, respectivamente), quando comparada ao controle e à bactéria A4 (86,7 e 90\%, respectivamente).

Foi possível observar características morfogênicas de diversas nas raízes oriundas dos explantes que foram induzidas através das três cepas de $A$. rhizogenes (Tabela 2). 
Tabela 2. Respostas morfogênicas apresentadas por explantes de folha e segmentos de caule de manjericão-roxo var. Dark Opal, 20 dias após inoculação com diferentes linhagens selvagens de Agrobacterium rhizogenes (30 explantes/linhagem de bactéria).

Table 2. Morphogenic responses of leaf explants and stem segments of purple basil var. Dark Opal, 20 days after inoculation with different wild strains of Agrobacterium rhizogenes (30 explants bacterial lineage.

\begin{tabular}{lcccccc}
\hline \multirow{2}{*}{$\begin{array}{c}\text { Linhagens de } \\
\text { Agrobacterium }\end{array}$} & \multicolumn{5}{c}{$\begin{array}{c}\text { Resposta Morfogênicas } \\
\text { (\% de explantes) }\end{array}$} \\
\cline { 2 - 7 } & \multicolumn{3}{c}{$\begin{array}{c}\text { Explante de folha } \\
\text { Explante de seg. de } \\
\text { caule }\end{array}$} \\
\cline { 2 - 7 } & $\mathrm{R}$ & $\mathrm{C}$ & $\mathrm{N}$ & $\mathrm{R}$ & $\mathrm{C}$ & $\mathrm{N}$ \\
\hline 8196 & 23,3 & 73,3 & 0 & 66,7 & 33,3 & 0 \\
\hline LBA & 73,3 & 23,3 & 0 & 90,0 & 0 & 6,7 \\
\hline A4 & 26,7 & 0 & 0 & 3,3 & 0 & 0 \\
\hline Controle & 73,3 & 3,4 & 0 & 76,7 & 3,3 & 0 \\
\hline R
\end{tabular}

R: Raiz; C: Calo; N: necrose

A Agrobactéria 8196 levou à formação intensa de calos $(73,3 \%)$ a partir de explantes de folha de manjericão-roxo (Tabela 2). Essa alta formação de calo foi acompanhada de uma menor produção de raízes, sendo o contrário observado nos explantes de segmento de caule, para a linhagem 8196 . Para a linhagem LBA houve uma intensa formação de raízes, sendo 90 e 73,3\% dos explantes de caule e folha, respectivamente, apresentaram formação de raízes, com menor produção calos a partir de folhas e sem a formação de calos nos explantes de caule. Porém, a partir de observações visuais as raízes formadas de explantes inoculados com a estirpe 8196 apresentaram maior diâmetro e menos ramificações do que as raízes originadas a partir de explantes inoculados com a linhagem LBA, que apresentaram morfologia muito similar às raízes dos explantes controle.

Outro fator importante é que os explantes de manjericãoroxo se mostraram mais resistentes à manipulação in vitro $\mathrm{e}$ ao processo de inoculação que os explantes de manjericãoverde, o que deve ser levado em consideração no momento da escolha do material vegetal a ser trabalhado. Outro efeito observado foi que no ensaio III ocorreu a senescência precoce das raízes.

A inoculação da estirpe R1601 nos explantes de folhas e segmentos de caule de duas variedades de manjericão cultivadas in vitro, induziu a produção de raízes transformadas. Para o manjericão-roxo var. Dark Opal, 100\% dos explantes inoculados apresentaram o desenvolvimento de raízes a partir das lesões, já nos explantes não inoculados observou-se formação de raízes apenas em 45\% dos explantes, sendo essas últimas raízes finas e frágeis.

As raízes produzidas em todos os explantes inoculados de manjericão-roxo var. Dark Opal apresentaram morfologia, taxa e hábito de crescimento diferentes das raízes formadas a partir dos explantes não inoculados. As raízes formadas nos explantes inoculados, apesar de não mensurados apresentaram-se visualmente mais espessas, de maior diâmetro e com crescimento mais rápido, sendo mais resistentes à manipulação (Figura 1).

As raízes começaram a surgir, tanto nos explantes inoculados, quanto naqueles não inoculados, aos 15 dias após a montagem do ensaio.

Diferentemente do manjericão-roxo, para o manjericãoverde var. Minete Anão apenas os explantes inoculados com a linhagem R1601 de A. rhizogenes apresentaram formação de raízes a partir das regiões lesionadas. Houve formação de raízes em 100\% dos explantes inoculados e nenhuma produção de raízes nos explantes controle sem inoculação (Figura 2).

Os explantes controle de manjericão-verde var. Minete Anão entraram em um rápido processo de senescência. Após 20 dias da montagem do experimento, 60\% dos explantes apresentavam-se com elevada taxa de necrose ou amarelecimento.

Culturas clonais de raízes geneticamente transformadas de manjericão-roxo var e de manjericão-verde var. Minete Anão foram estabelecidas a partir de segmentos individualizados que se formaram a partir dos sítios de infecção da linhagem R1601 dos explantes de folha.

Raízes induzidas em segmentos de folha de manjericão co-cultivadas com a linhagem $\mathrm{R} 1601$ de A. rhizogenes cresceram em meio livre de hormônios ou reguladores de crescimento, mostrando as características típicas de raízes transformadas geneticamente, tais como elevada taxa de crescimento e grande ramificação.

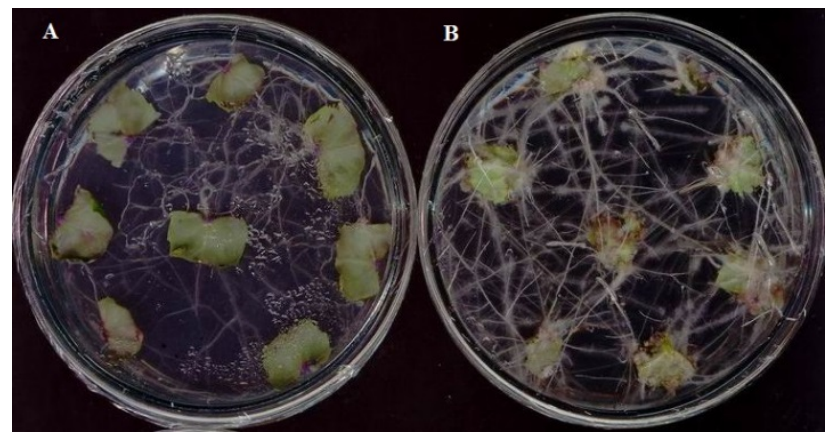

Figura 1. Explantes de manjericão-roxo (A) inoculados e (B) não inoculados com a estirpe R1601 de Agrobacterium rhizogenes, 20 dias após a inoculação. Escala 1:0,97

Figure 1. Purple basil explants (A) inoculated with Agrobacterium rhizogenes strain R1601 and (B) uninoculated basil-purple explants, 20 days after inoculation. Scale 1:0.97

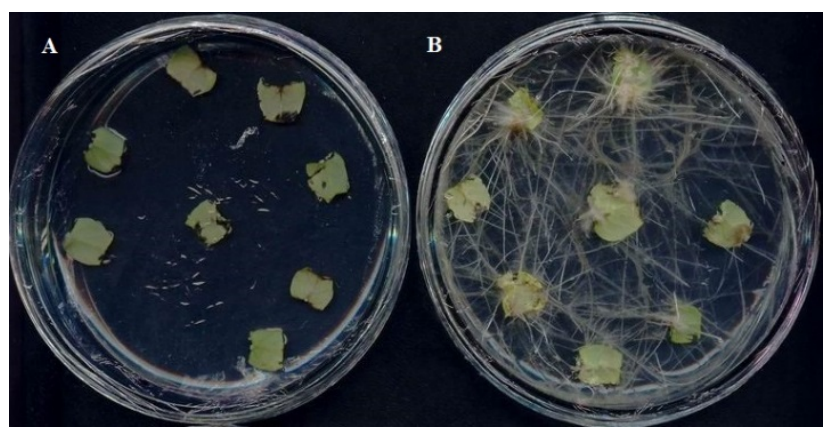

Figura 2. Explantes de manjericão-verde var. Minete Anão (A) inoculados e (B) não inoculados com a estirpe R1601 de $A$. rhizogenes, 20 dias após a inoculação. Escala 1:0,99

Figure 2. Explants of basil-green var. Rhesus dwarf rearing inoculated and not inoculated with A. rhizogenes strain R1601, 20 days after inoculation. Scale 1:0.99

Para manjericão-roxo selecionou-se 8 clones (Figura 3), e para manjericão-verde var. Minete Anão selecionou-se 6 clones (Figura 4). Foram escolhidos os segmentos radiculares de crescimento mais vigoroso quando ainda ligado ao explante. Os clones selecionados apresentaram características, principalmente no que se refere a presença de pelos radiculares (Figuras 3 e 4). 
Em nenhum dos explantes, tanto inoculados por agrobactéria quanto não inoculados, observou-se expressiva formação de calos. A formação das raízes ocorreu de forma direta. Diferente do que foi observado nos explantes de folha inoculados com a linhagem selvagem de Agrobacterium rhizogenes 8196.

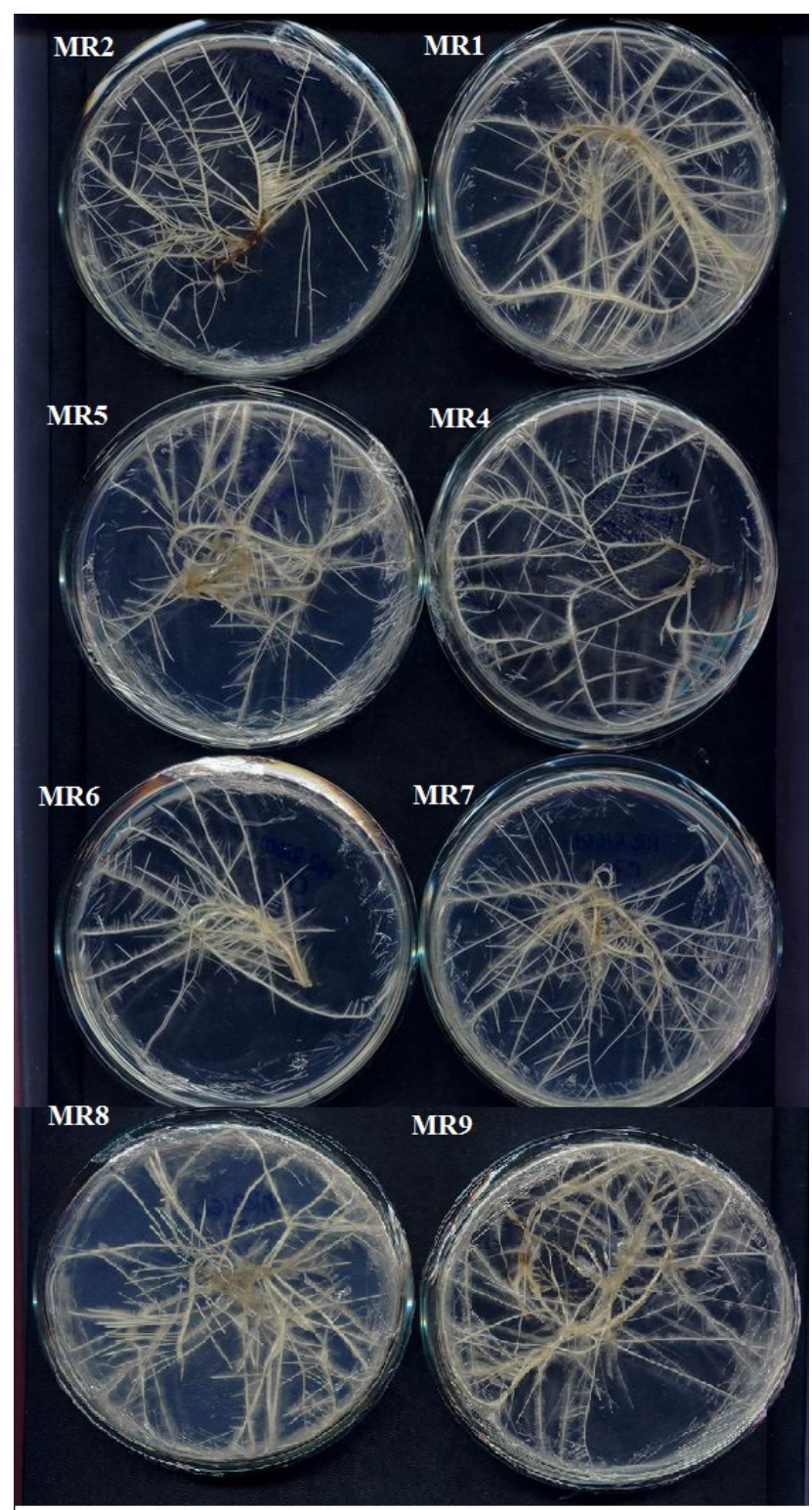

Figura 3. Culturas de raízes de manjericão-roxo var. Dark Opal, 37 dias após serem excisadas dos explantes (clones MR1, MR2, MR4, MR5, MR6, MR7, MR8 e MR9). Raízes obtidas a partir da inoculação de explantes de folha com a estirpe R1601 de $A$. rhizogenes.

Figure 3. Root cultures of basil-purple var. Dark Opal, 37 days after being excised from the explants (clones MR1, MR2, MR4, MR5, MR6, MR7, MR8 and MR9). These roots were obtained from the inoculation of leaf explants with A. rhizogenes strain R1601.

Os clones MR1, MR5, MR6, MR8 e MR9 de manjericãoroxo apresentaram maior quantidade de pêlos radiculares bem finos. Os clones MR2, MR4 e MR7 apresentam menor densidade de pêlos finos (Figura 3). As raízes primárias do clone MR4 foram mais finas que nos demais clones. O clone MR6 apresentou menor desenvolvimento, porém com raízes primárias espessas e recobertas de pequenos e finos pêlos. Os clones MR5, MR6, MR7 e MR9 apresentaram eventual formação de pequenos calos, de coloração arroxeada.

Como pode ser observado na Figura 4, todas as culturas clonais de manjericão-verde var. Minete Anão apresentaram formação de grande quantidade de pequenos e finos pêlos radiculares, apresentando de uma forma geral morfologia bem similar entre os clones. À exceção dos clones MV3 e MV6 que eventualmente produziram pequenos calos. Porém, diferente dos calos produzidos por alguns dos clones da var. Dark Opal, observou-se a coloração destes era branca.

As culturas clonais de manjericão-verde var. Minete Anão apresentaram também as características típicas de culturas de raízes transformadas geneticamente por $A$. rhizogenes, ou seja, rápido crescimento em meio de cultura livre de reguladores de crescimento (Figura 4).

$\mathrm{Na}$ Figura 5 pode-se observar o resultado do gel a partir da Reação em Cadeia da Polimerase (PCR) do DNA dos tecidos das plantas de raízes transformadas, para confirmar a integração do DNA bacteriano no DNA genômico das raízes. As raízes foram eficientemente induzidas mediante a inoculação de explantes de manjericão-roxo var. Dark Opal, manjericão-verde com Agrobacterium rhizogenes, e expressaram o fenótipo típico de raízes pilosas ("hairyroots").

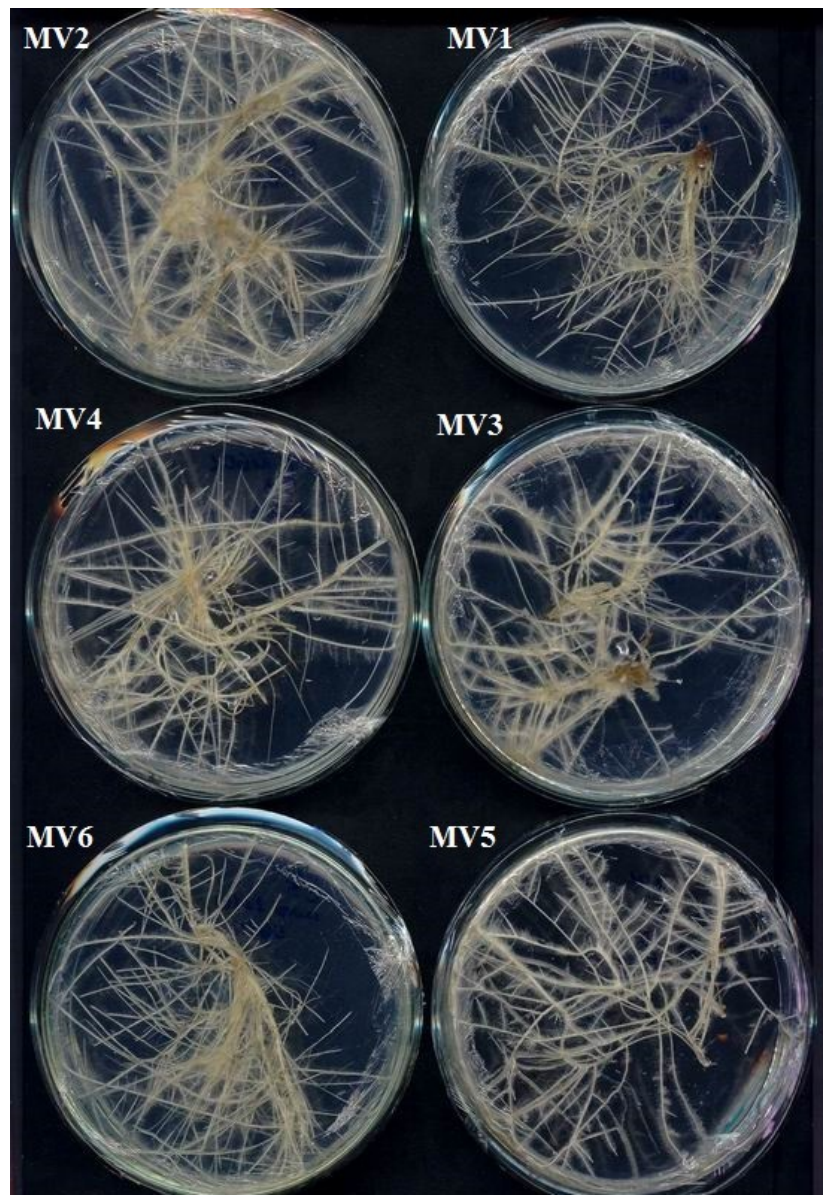

Figura 4. Culturas de raízes de manjericão-verde var. Minete Anão, 37 dias após serem excisadas dos explantes (clones MV1, MV2, MV3, MV4, MV5 e MV6). Essas raízes foram obtidas a partir da inoculação de explantes de folha com a estirpe R1601 de $A$. rhizogenes.

Figure 4. Cultures of roots of basil-green var. (MV1, MV2, MV3, MV4, MV5 and MV6 clones). These roots were obtained from the inoculation of leaf explants with A. rhizogenes strain R1601. 
Para a avaliação da transformação genética foi feita a extração do DNA de amostras das raízes inoculadas, plantas não inoculadas (controle negativo) e de plasmídeos purificados (controle positivo contendo o gene marcador nptII que codifica a enzima neomicina fosfotransferase II nptII) (BHATTACHARYYA et al., 2014; NYABOGA et al., 2015). A amplificação do fragmento do gene nptII, nas amostras de raízes correspondentes, sugere a integração do TDNA no genoma do manjericão-roxo var. Dark Opal e do manjericão-verde var. Minete Anão.

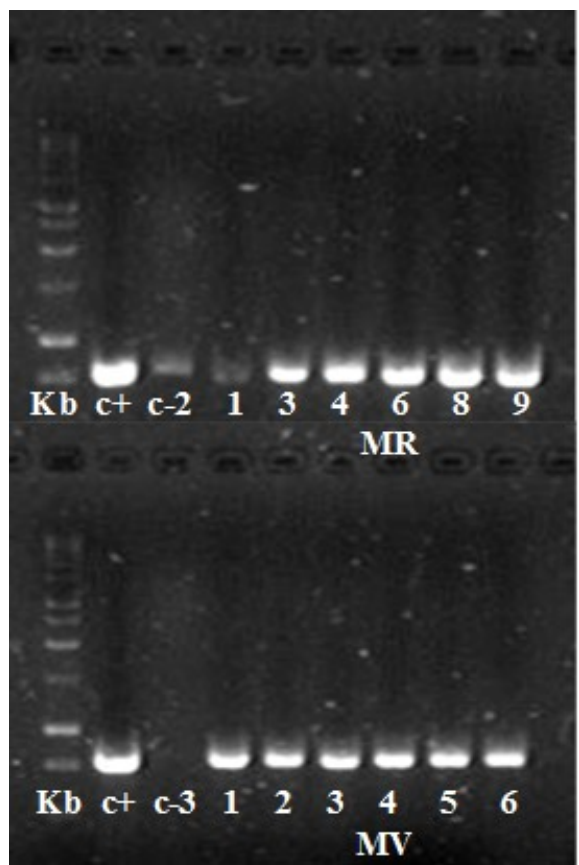

Figura 5. Padrão dos produtos da Análise por Reação em Cadeia da Polimerase (PCR) do DNA de tecidos de manjericão-roxo var. Dark Opal, manjericão-verde, var. Legenda: Kb: Marcador de tamanho; C+: Plasmídio com gene nptII; C-2: DNA genômico de planta de manjericão-roxo não transformada; C-3: DNA genômico de planta de manjericão-verde não transformada; MR1 a MR9: Clones de manjericão-roxo transformados; MV1 a MV6: Clones de manjericão-verde transformados.

Figura 5. Standard of the Polymerase Chain Reaction Analysis (PCR) products of the basal tissue DNA var. Dark Opal, basilgreen, var. Legend: $\mathrm{Kb}$ : Molecular weight marker; $\mathrm{C}+$ : Plasmid with nptII gene; C-2: Genomic DNA from untransformed basilpurple plant; C-3: genomic DNA from untransformed basilgreen plant; MR1 to MR9: Transformed basil-purple clones; MV1 to MV6: Transformed basil-green clones.

\section{DISCUSSÃO}

A implementação do cultivo in vitro a partir de sementes comerciais, permitiu o desenvolvimento de protocolo específico de assepsia. Desta maneira, tornou-se possível a produção de plântulas a partir de sementes in vitro. A contaminação endógena visualmente observada nos ensaios I e II (fungos e bactérias) exige ainda que se domine técnicas de cultivo e produção de plantas em casa de vegetação. A continuidade destes estudos poderá em um futuro próximo permitir o uso de explantes extraídos de plantas adultas.

Apesar de ter ocorrido a infecção das estirpes selvagens (A4, LBA e 8196), 25 dias após a retirada dos explantes cultura, as raízes necrosaram, o que sugere que as mesmas não estavam transformadas geneticamente.

Assim como observado nos ensaios I e II, no ensaio III houve grande destaque para a linhagem de $A$. rhizogenes A4. Thwe et al. (2016) também observou que esta linhagem apresentou $100 \%$ de eficiência na infecção de Fagopyrum tataricum. A maior virulência e eficiência na transformação de raízes por A4 também foi observada no trabalho realizado por Mahesh; Jeyachandran, (2011) quando comparou a A4 e ATCC 15834 na infecção da espécie vegetal Taraxacum officinale. Para Mahesh; Jeyachandran, (2011), o co-cultivo é uma etapa de extrema importância no processo de transformação, uma vez que é nessa fase que ocorre a transferência e integração do T-DNA com a célula vegetal. Dessa forma, para o uso dessa linhagem é necessário o equilíbrio na concentração da bactéria e explantes no cocultivo para que não ocorra competição entre ambas.

As diferenças observadas no padrão de oxidação e necrose do manjericão-verde nos explantes de folha e segmento do caule pode estar correlacionado à produção de hormônios vegetais, uma vez que o processo de transformação, com integração da região T-DNA do plasmídio bacteriano ao genoma vegetal, ocorrem modificações na resposta fisiológica da planta, no que diz respeito à síntese de hormônios e à sensibilidade aos mesmos (SETAMAM et al., 2014).

Diferentes estirpes de bactéria e diferentes partes vegetais utilizadas na inoculação podem gerar diferentes respostas morfogênicas (SARAVANAKUMAR et al., 2012). Mallol et al. (2001), verificaram que explantes de Panax ginseng, quando inoculados com a linhagem A4 de A. rhizogenes podem apresentar três diferentes morfologias, e essas dependem diretamente do conjunto de fragmentos de genes transferidos para a planta no momento da infecção. Foram identificados genes chamados aux, responsáveis pela produção de uma quantidade adicional de auxinas, que quando presente, confere às raízes um aspecto de calo.

Gangopadhyay et al. (2010) observaram que a infecção de ATCC 15834 de $A$. rhizogenes utilizando explante de folhas da espécie vegetal Plumbago indica induziu maior proporção de raiz transformada, quando comparada a indução de calo, assim como resultou em maiores teores tanto de matéria seca, como de plumbagina (metabólito característico dessa espécie), quando comparados as cepas A4 e LBA. Essas diferenças na morfologia dos explantes inoculados com as agrobactérias podem ser usadas para caracterizar as diferenças entre os conjuntos de genes transferidos por cada bactéria, o que torna cada processo de interação único.

Pode ser uma importante informação o fato da linhagem selvagem 8196, na infecção de manjericão roxo, ter mostrado grande capacidade de induzir a formação de calos. Já que esses calos possuem habilidade de crescer em meio livre de hormônios e reguladores de crescimento, tornando essa espécie bastante promissora na produção de metabólitos secundários. Nesse sentido, a produção desses metabólitos pode ser modificada em cada caso, ocorrendo mudança na quantidade e no perfil das substâncias sintetizadas (THWE et al., 2016).

As raízes produzidas nos explantes controle de manjericão-roxo foram transferidas para meio de crescimento livre de hormônios e apresentaram desenvolvimento, sendo esse resultado não encontrado na literatura. Uma hipótese 
para esse resultado seria a existência de auxina endógena dessa espécie. Isso porque no controle não houve infecção bacteriana e, portanto, não ocorreu a transferência do gene aux localizado na região TR de pRi T-DNA da A. rhizogenes, o que aumentaria os níveis de proteínas envolvidas na biossíntese desse hormônio na célula hospedeira (KARUPPUSAMY 2009; GEORGIEV et al., 2012; NESTER, 2015).

Apesar dos avanços observados em relação aos ensaios I e II, no ensaio III, também foram identificadas dificuldades como: senescência precoce em relação a estabilidade na produção de raízes, uma vez que não foi possível obter grande quantidade de raízes em um sub-cultivo originado a partir de pouco inóculo inicial, o que é característico das raízes transformadas (SETAMAM et al., 2014).

Conforme descrito nos resultados, nesse ensaio a linhagem R1601 de Agrobacterium rhizogenes induziu 100\% dos explantes inoculados, apresentando raízes a partir das lesões, para o manjericão-roxo. No trabalho realizado por Zahanis et al. (2014), resultados semelhantes foram obtidos com a estirpe R1000 de A. rhizogenes na produção de 100\% de raízes transformadas da planta Centella asiática. Esses autores também investigaram as cepas A4 e LBA, onde concluíram que todas as linhagens foram capazes de produzir raízes transformadas, com $50 \%$ e $33 \%$ de emergência de raízes, respectivamente. Segundo os mesmos, a obtenção de raízes transformadas também é influenciada pelas diferenças nas fontes de explante, sendo a melhor indução, com os explantes foliares.

$\mathrm{O}$ estabelecimento de diferentes clones para as culturas transformadas é de grande importância quando se tem por objetivo a produção e acúmulo de metabólitos secundários (GAI et al., 2015). Nesse aspecto, Yu et al. (1996) observaram que o comportamento de sete diferentes clones de Solanum aviculare, transformados pela estirpe A4 de Agrobacterium rhizogenes não diferiu quanto à taxa de crescimento e ao acúmulo de alcalóides. Porém, morfologicamente, os clones apresentaram variações consideráveis, inclusive após serem replicadas. Isso pode ser explicado pelo surgimento de pequenos nódulos calosos, que conferem certa instabilidade genética ao material vegetal.

Bais et al. (2002) obtiveram diferentes culturas clonais de raízes de manjericão transformadas geneticamente pela linhagem ATCC-15834. Essas culturas clonais acumularam em média $65,1 \pm 4,8$ g. $\mathrm{L}^{-1}$ de massa fresca, representando um acúmulo de massa fresca cerca de 6,51 vezes maior que culturas de raízes não transformadas.

No presente trabalho, raízes foram eficientemente induzidas mediante a inoculação de explantes de manjericãoroxo e de manjericão-verde com $A$. rhizogenes, uma vez que expressaram fenótipo típico de raízes pilosas "hairy-roots". Tais resultados abrem novas possibilidades de ensaios para o manjericão, pois essa espécie é conhecida por apresentar uma grande quantidade de metabólitos especiais, como o ácido rosmarínico (éster do ácido caféico, usado como antioxidante) e seu valioso óleo essencial (rico em linalol e mentol) (BILAL et al., 2012). Essas raízes podem ser utilizadas no estudo das condições ambientais que modulam a produção, biossíntese e acumulação nos tecidos, dessas substâncias.

Nessa pesquisa foi possível confirmar a presença de bandas amplificadas para o controle positivo do plasmídio contendo o gene nptII. Esse gene nptII é o gene marcador de seleção mais utilizado em transformação genética de plantas. Ele codifica a enzima neomicina fosfotransferase II (NPT II), também chamada aminoglicosídeo 3'-fosfotransferase II, que atua transferindo o grupamento $\gamma$ fosfato do ATP para um grupo 3-hidroxil da porção amino-hexose dos antibióticos aminoglicosados, como a canamicina, a neomicina, a geneticina e a paromicina, que assim são detoxificados por fosforilação (COHEN; KRENS, 2012).

A continuidade destes estudos é essencial para que seja possível conhecer melhor todos os fatores envolvidos na manipulação in vitro da espécie estudada. O manjericão é uma espécie vegetal que apresenta considerável valor econômico, social e ecológico, o que justifica aplicação da biotecnologia.

\section{CONCLUSÕES}

A inoculação de explantes oriundo de plantas cultivadas in vitro foi melhor para a obtenção de raízes geneticamente modificadas.

Os explantes de manjericão-roxo se mostraram mais resistentes à manipulação in vitro e ao processo de inoculação que os explantes de manjericão-verde.

Dentre as linhagens selvagens de $A$. rhizogenes avaliadas, as que apresentaram características favoráveis para produção de "hairy roots" em manjericão foram as linhagens A4, LBA e 8196 respectivamente. Entretanto a foi a linhagem laboratorial R1601 apresentou o melhor desempenho.

Foram obtidas culturas clonais das raízes transformadas, indicando potencial de uso para estudos de produção de metabólitos de interesse.

\section{AGRADECIMENTOS}

Os autores agradecem o apoio financeiro recebido pelo CNPq e pela FAPERJ para realização deste estudo.

\section{REFERÊNCIAS}

ATANASOV, A. G.; WALTENBERGER, B.; PFERSCHYWENZIG, E. M.; LINDERD, T.; WAWROSCHA, C.; UHRINE, P.; TEMMLF, V.; WANGA, L.; SCHWAIGERB, S.; HEISSA, E. H.; et al. Discovery and resupply of pharmacologically active plant-derived natural products: A review. Biotechnology Advances, v. 33 , n. $8, \quad$ p. 1582-1614, 2015. DOI: https://doi.org/10.1016/j.biotechadv.2015.08.001

BAIS, H. P.; WALKER, T. S.; SCHWEIZER, H. P.; VIVANCO, J. M. Root specific elicitation and antimicrobial activity of rosmarinic acid in hairy root cultures of Ocimum basilicum. Plant Physiology and Biochemistry, Paris, v. 40, p. 983-995, 2002. DOI: https://doi.org/10.1016/S0981-9428(02)01460-2

BHATTACHARYYA, N.; SINGH, H. R.; AGARWALA, N.; BHAGAWATI, P.; AHMED, G.; DAS, S. Agrobacterium mediated transfer of $n p t I I$ and gus genes in Camellia assamica. Journal of Agricultural Biotechnology and Sustainable Development, Nigeria, v. 6 , n. 2, p. 22-28, 2014. DOI: https://dx.doi.org/10.5897/JABSD2013.0218

BILAL, A.; JAHAN, N.; AHMED, A.; BILAL, S. N.; HABIB, S.; HAJRA, S. Phytochemical and pharmacological studies on Ocimum basilicum linn - a 
review. International Journal of Current Research and Review, Nagpur, v. 4 n. 23, p. 73-83, 2012.

BORGO, L.; MARUR, C. J.; VIEIRA, L. G. E. Effects of high proline accumulation on chloroplast and mitochondrial ultrastructure and on osmotic adjustment in tobacco plants. Acta Scientiarum. Agronomy, Maringá, v. 37, n. 2, p. 191-199, 2015. DOI: http://dx.doi.org/10.4025/actasciagron.v37i2.19097

CHENNI, M.; ABED, D. E.; RAKOTOMANOMANA, N.; FERNANDEZ, X.; CHEMAT, F. Comparative study of essential oils extracted from Egyptian basil leaves (Ocimum basilicum L.) using hydro-distillation and solvent-free microwave extraction. Molecules, Basel, v.21, n.1, p.113, 2016. http://dx.doi.org/10.3390/molecules21010113

CHHETRI, B. K.; ALI, N. A.; SETZER, W. N. A Survey of chemical compositions and biological activities of Yemeni aromatic medicinal plants. Medicines, Basel, v. $2, \quad \mathrm{n} \quad 2, \quad$ p. $67-92, \quad 2015$. DOI: http://dx.doi.org/10.3390/medicines2020067

CIAU-UITZ, R.; MIRANDA-HAM, M. L.; COELLOCOELLO, J.; CHÍ, B.; PACHECO, L. M.; LOYOLAVARGAS, V. M. Indole alkaloid production by transformed and non-transformed root cultures of Catharanthus roseus. In Vitro Cellular \& Developmental Biology - Plant, United States, v. 30, n. 1, p. 84-88, 1994. http://dx.doi.org/10.1007/BF02632126

COHEN, A.; KRENS, F. A. Genetic transformation in the breeding of flower bulbs. Floric. Ornam. Biotechnol., Isleworth, v. 6, p. 24-34, 2012.

CRAGG, G. M.; NEWMAN, D. J. Natural products: a continuing source of novel drug leads. Biochimica et Biophysica Acta, Amsterdam, v. 1830, n. 6, p. 36703695, 2013.

DOI: https://doi.org/10.1016/j.bbagen.2013.02.008

FERREIRA, M. E.; GRATTAPAGLIA, D. Introdução ao uso de marcadores moleculares em análise genética. 2a. ed. Brasília: EMBRAPA CENARGEN, 1995. pp. 220.

FILOVÁ, A. Production of secondary metabolites in plant tissue cultures. Research Journal of Agricultural Science, Srinagar, v.46, n.1, p.236-245, 2014. http://www.rjas.ro/volume_detail/25

GAI, Q.Y.; JIAO, J.; LUO, M.; WEI, Z. F.; ZU, Y. G.; MA, W.; FU, J. Y. Establishment of hairy root cultures by Agrobacterium rhizogenes mediated transformation of Isatis tinctoria L. for the efficient production of flavonoids and evaluation of antioxidant activities. Plos One, San Francisco, v. 10, n. 3, 2015. e0119022. DOI: https://dx.doi.org/10.1371/journal.pone.0119022

GANGOPADHYAY, M.; DEWANJEE, S.; BHATTACHARYYA, S.; BHATTACHARYA, S. Effect of different strains of Agrobacterium rhizogenes and nature of explants on Plumbago indica hairy root culture with special emphasis on root biomass and plumbagin production. Natural Products Communications, Westerville, v. 5, n. 12, p. 1913-1916, 2010.

GEORGIEV, M. I.; AGOSTINI, E.; LUDWIG-MÜLLER, J.; $\mathrm{XU}, \mathrm{J}$. Genetically transformed roots: from plant disease to biotechnological resource. Trends in Biotechnology, Netherlands, v. 30, n. 10, p. 528-537, 2012. DOI: https://dx.doi.org/10.1016/j.tibtech.2012.07.001
KARUPPUSAMY, S. A review on trends in production of secondary metabolites from higher plants by in vitro tissue, organ and cell cultures. Journal of Medicinal Plants Research, Nigeria, v. 3, n. 13, p. 1222-1239, 2009.

KINGHORN, A. D.; PAN, L.; FLETCHER, J. N.; CHAI, H. The relevance of higher plants in lead compound discovery programs. Journal of Natural Products, Columbus, v. 74, n. 6, p. 1539-1555, 2011. DOI: http://dx.doi.org/10.1021/np200391c

MAHESH, A.; JEYACHANDRAN, R. Agrobacterium rhizogenes mediated hairy root induction in Taraxacum officinale and analysis of sesquiterpene lactones. Plant Biosystems, Bologna, v. 145, n. 3, p. 620-626, 2011. DOI: http://dx.doi.org/10.1080/11263504.2011.584702

MALLOL, A.; CUSIDÓ, R. M.; PALAZÓN, J.; BONFILL, M; MORALES, C.; PIÑOL, M. T. Ginsenoside production in different phenotypes of Panax ginseng transformed roots. Phytochemistry, NY, v. 57, p. 365371. 2001. DOI: https://doi.org/10.1016/S00319422(01)00062-0

MURASHIGE T.; SKOOG F. A. A revised medium for a rapid growth and bioassays with Tobacco tissues cultures. Physiologia Plantarum, København, v. 15, n. 7, p. 473479, 1962. DOI: http://dx.doi.org/10.1111/j.13993054.1962.tb08052.x

NESTER, E. W. Agrobacterium: Nature's genetic engineer. Frontiers in Plant Science, Switzerland, v. 5, p. 730, 2015. DOI: https://dx.doi.org/10.3389/fpls.2014.00730

NYABOGA, E.; TRIPATHI, J. N.; MANOHARAN, R.; TRIPATHI, L. Agrobacterium-mediated genetic transformation of yam (Dioscorea rotundata): an important tool for functional study of genes and crop improvement. Frontiers in Plant Science, Switzerland, v. $5, \quad$ p. $463.42015 . \quad$ DOI: https://dx.doi.org/10.3389/fpls.2014.00463

PEREIRA, G. A; CORREA, L. S.; BOLIANI, A. C. Desinfestação e estabelecimento in vitro de explantes de bananeira 'Grande Naine' em diferentes concentrações de hipoclorito de sódio. Revista Brasileira de Fruticultura, Jaboticabal, v. 33, n. Especial, p. 222-226, 2013. DOI: http://dx.doi.org/10.1590/S0100-29452011000500026

SARAVANAKUMAR, A.; ASLAM, A.; SHAJAHAN, A. Development and optimization of hairy root culture systems in Withania somnifera (L.) Dunal for withaferinA production. African Journal of Biotechnology, Nairobi, v. 11, n. 98, p. 16412-16420, 2012. DOI: https://doi.org/10.5897/AJB11.3867

SETAMAM, N. M.; SIDIK, N. J.; RAHMAN, Z. A.; ZAIN, C. R. C. M. Induction of hairy roots by various strains of Agrobacterium rhizogenes in different types of Capsicum species explants. BMC Research Notes, London, v. 7, p. 414-421, 2014. DOI: https://doi.org/10.1186/1756-0500$7-414$.

SRIVASTAVA, S; CONLAN, X. A.; ADHOLEYA, A; CAHILL, D. M. Elite hairy roots of Ocimum basilicum as a new source of rosmarinic acid and antioxidants. Plant Cell, Tissue and Organ Culture. Berlin, v. 126, n. 1, p. 19-32, 2016. DOI: http://dx.doi.org/10.1007/s11240-0160973-x

TADA, H.; MURAKAMI, Y; OMOTO, T.; SHIMOMURA, K.; ISHIMARU, K. Rosmarinic acid and related 
phenolics in hairy root cultures of Ocimum basilicum. Phytochemistry, NY, v. 42, n. 2, p. 431-434, 1996. DOI: https://doi.org/10.1016/0031-9422(96)00005-2

THWE, A.; ARASU, M. V.; LI, X.; PARK, C. H.; KIM, J. S.; Al-DHABI, N. A.; PARK, S. U. Effect of Different Agrobacterium rhizogenes strains on hairy root induction and phenylpropanoid biosynthesis in tartary buckwheat (Fagopyrum tataricum G.). Frontiers in Microbiology, Lausanne, v. 7, n. 318, 2016. DOI: http://dx.doi.org/10.3389/fmicb.2016.00318.

YU, S.; KWOK, K. H.; DORAN, P. M. Effect of sucrose, exogenous product concentration, and other culture conditions on growth and steroidal alkaloid production by Solanum aviculare hairy roots. Enzyme and Microbial Technology, NY, v. 18, n. 4, p. 238-243, 1996. DOI: https://doi.org/10.1016/0141-0229(95)00057-7

ZAHANIS, Z.; MANSYURDIN, M.; NOLI, Z. A.; BACHTIAR, A. Induction of hairy roots of Pegagan (Centella asiatica L.) urban using several explant sources with several Agrobacterium rhizogenes strains in vitro. International Journal on Advanced Science, Engineering and Information Technology, Indonesian, v. 4, n. 4, p. 286-289, 2014. DOI: http://dx.doi.org/10.18517/ijaseit.4.4.418 